\title{
Penerapan Prinsip Pertanggungjawaban Negara Terhadap Kasus Pelanggaran HAM Etnis Rohingya Di Myanmar
}

\author{
Setiyani ${ }^{*}$, J oko Setiyono ${ }^{2}$ \\ 1Fakultas Syariah \& Hukum, Universitas Islam Negeri Walisongo Semarang \\ 2Fakultas Hukum, Universitas Diponegoro \\ tiyayani75@gmail.com
}

\begin{abstract}
The state as a human duty bearer has an obligation to guarantee the implementation of human rights in its jurisdiction. If the state does not fulfill its obligations, the state has committed human rights violations. Human rights violations that occur will raise questions about who will be responsible for a human rights violation. Human rights violations occurred in Myanmar that befell the Rohingya ethnic group have occurred since 1962. It began with discrimination and resulted in gross human rights violations. This article was made to find out how the state of Myanmar is responsible for human rights violations that occurred. This paper was made using the doctrinal research method with a literature review to collect data. As a state of law, Myanmar has an obligation to guarantee the human rights of its citizens without discrimination. Myanmar in this case must be held responsible for the loss and damage. Human Rights violation is one of state wrongful action that one form its responsibility is to take action to stop and uphold the law and human rights of the perpetrators and to guarantee that the human rights violation will not happening again.
\end{abstract}

Keymords: State Responsibility; Human Rights Violations; Sovereignity.

\begin{abstract}
ABSTRAK
Negara sebagai pemangku HAM mempunyai kewajiban untuk menjamin pelaksanaan HAM di wilayah negaranya. Apabila negara tidak menunaikan kewajibannya maka negara telah melakukan pelanggaran HAM. Pelanggaran HAM yang terjadi akan menimbulkan pertanyaan tentang siapa yang akan bertanggung jawab atas suatu pelanggaran HAM. Pelanggaran HAM yang terjadi di Myanmar yang menimpa etnis Rohingya telah terjadi sejak tahun 1962. Diawali dengan diskriminasi dan berujung pada pelanggaran HAM berat. Artikel ini dibuat untuk mengetahui bagaimana pertanggungjawaban negara Myanmar atas pelanggaran HAM yang terjadi. Tulisan ini dibuat menggunakan metode penelitian doktrinal dengan kajian pustaka untuk mengumpulkan data. Sebagai negara hukum, Myanmar memiliki kewajiban untuk menjamin HAM warga negaranya tanpa unsur diskriminasi. Myanmar dalam kasus ini harus bertanggung jawab kerugian dan kerusakan yang terjadi. Pelanggaran HAM merupakan salah satu state wrongfull action adapun bentuk tanggung jawabnya adalah dengan melakukan tindakan penghentian dan penegakan hukum dan HAM terhadap pelakunya serta menjamin bahwa pelanggaran HAM yang serupa tidak akan terjadi lagi.
\end{abstract}

Kata Kunci: Pertanggungjawaban Negara; Pelanggaran HAM; Berdaulat. 
Jurnal Pembangunan Hukum Indonesia

Volume 2, Nomor 2, Tahun 2020
Program Studi Magister Ilmu Hukum Fakultas Hukum Universitas Diponegoro

\section{A. PENDAhULUAN}

Negara-negara yang berada di wilayah Asia Tenggara (ASEAN) memiliki keanekaragaman etnis, ras, dan agama yang tersebar di masing-masing negara. Myanmar sebagai salah satu negara ASEAN yang mayoritas penduduknya beragama Budha dan memiliki banyak etnis. Populasi negara Burma (Myanmar) memiliki sekitar 135 kelompok etnis dan sub kelompok. Etnis Burma adalah kelompok terbesar (sekitar 68\%). Kemudian Shan (9\%), Karen (7\%), Rakhine atau Arakan (4\%), dan Mon (2\%) (Human Rights Counsil, 2018). Selain itu, terdapat etnis Kachin, Chin, Karenni, dan Rohingya (Human Rights Counsil, 2018). Banyaknya etnis yang terdapat di Myanmar telah menimbulkan konflik antara etnis mayoritas dan minoritas di dalam negaranya salah satunya adalah konflik etnis Rohingya. Etnis Rohingya yang hidup di satu wilayah negara Myanmar telah lama terlibat konflik. Etnis Rohingya merupakan etnis muslim dan minoritas (Sawal, 2017).

Pada Oktober 2016, kekerasan dan diskriminasi terhadap etnis Rohingya telah mengejutkan publik secara regional maupun internasional. Dunia pun menyoroti tindakan pelanggaran Hak Asasi Manusia (HAM) yang terjadi di Myanmar. Akibat dari pelanggaran HAM ini adalah eksodus besar-besaran warga Rohingya yang mengungsi ke negara-negara sekitar Myanmar seperti Indonesia, Malaysia, Thailand, dan India. Hal mengejutkan lainnya, United Nation High Commission for Refugees (UNHCR) memperkirakan eksodus besar-besaran ini sudah dimulai sejak tahun 2012 yakni sejak munculnya suatu gerakan Rohingya Elimination Group yang bertujuan menghapus dan memusnahkan etnis Rohingya dari tanah Arakan. Gerakan ini pun memaksa ribuan warga Rohingya untuk tinggal di kamp-kamp konsentrasi dan menyebabkan ratusan orang meninggal dunia (Kurniawan, 2017).

Tidak seperti etnis lain yang diakui kewarganegaraannya oleh Myanmar, etnis Rohingya dianggap sebagai penduduk sementara. Dianggap sebagai orang pendatang, etnis Rohingya tidak diperbolehkan bekerja sebagai pengajar, perawat, abdi masyarakat atau dalam layanan masyarakat, mereka dianggap sebagai orang-orang yang tak bernegara dan tidak diakui oleh pemerintah Myanmar (Pudjibudono, 2019). Tentara Myanmar kerapkali meminta uang dari mereka dan ketika mereka tidak dapat membayar, mereka akan ditahan dan disiksa. Masyarakat Rohingya juga mengalami penyiksaan secara religi. Hampir seluruh masyarakat Rohingya adalah beragama Islam. Sejak 1962, tidak ada Masjid baru yang dibangun. Bahkan para pemimpin agama telah dipenjara karena merenovasi Masjid. Wakil Sekretaris Jenderal PBB untuk Urusan Kemanusiaan dan Koordinator Bantuan Darurat, Valerie Amos, menyatakan bahwa Rohingya dipandang sebagai salah satu komunitas paling tertindas di dunia (Siba, \& Qamari'ah, 2018).

Konsep HAM secara jelas telah menjelaskan posisi negara dalam aspek HAM. Negara sebagai entitas yang mempunyai power dianggap mampu 
Jurnal Pembangunan Hukum Indonesia

Volume 2, Nomor 2, Tahun 2020
Program Studi Magister Ilmu Hukum Fakultas Hukum Universitas Diponegoro untuk menjalankan misi pemajuan HAM secara global. Konsekuensi dari hal ini adalah negara akan selalu dituntut untuk melaksanakan kewajibannya dalam rangka pemajuan HAM. Dalam prinsip HAM negara adalah sebagai pemangku HAM (duty bearer) dan setiap individu dalam naungan yurisdiksinya merupakan pemegang HAM (rights holder). Kewajiban utama yang harus diemban negara adalah kewajiban untuk menghormati (to respect), kewajiban untuk memenuhi (to fulfill), dan kewajiban untuk melindungi (to protect) (Rahayu, 2015). Selain itu negara juga wajib mengontrol dan menjamin berjalannya pelaksanaan HAM bagi setiap individu yang berada di bawah yurisdiksinya. Adapun sebuah fenomena pelanggaran HAM, secara struktural korban dari pelanggaran HAM adalah warga negara baik individu maupun kelompok. Pelanggaran HAM dapat dikaitkan dengan negara c.q pemerintah apabila pelanggaran tersebut dilakukan oleh badan atau pejabat negara maupun kabinet atau parlemen yang membuat atau menjalankan kebijakan negara (Zaini, 2016).

Posisi dan peran negara sebagai pemangku HAM secara jelas telah menunjukkan bahwa semua aspek yang menyangkut penghormatan, perlindungan, pemenuhan dan pemajuan HAM adalah tanggung jawab negara. Apabila negara tidak dapat menjalankan kewajibannya sebagai pemangku HAM maka negara akan diberi label telah melakukan pelanggaran HAM. Kondisi ini telah melahirkan suatu prinsip pertanggungjawaban negara (state responsibility) dimana negara dapat diminta pertanggungjawaban atas pelanggaran HAM yang menimpa suatu kelompok atau individu. Secara garis besar, tanggung jawab negara akan muncul apabila negara telah melakukan tindakan yang dianggap salah secara internasional.

Pertanggungjawaban negara akan timbul apabila suatu negara melakukan pelanggaran terhadap peraturan Hukum Internasional atau perbuatan sebuah negara yang merugikan negara berdaulat lainnya. Adapun dalam hukum nasional, pertanggungjawaban negara timbul karena negara merupakan suatu entitas yang berdaulat dan memiliki power untuk melakukan sesuatu atau tidak melakukan sesuatu terhadap warga yang berada di bawah yurisdiksinya (Philip, 2016).

Namun dalam perkembangannya, prinsip pertanggungjawaban negara erat kaitannya dengan HAM. Sehingga dalam konteks penegakan HAM negara juga menjadi aktor utama yang bertanggung jawab untuk melindungi, memenuhi, dan menghormati HAM. Dalam instrumen hukum internasional tanggung jawab negara dapat dilihat dalam mukaddimah Deklarasi Universal HAM (DUHAM), International Convenant on Civil and Political Rights (ICCPR), dan Internatonal Convenant on Economic, Social and Cultural Rights (ICESCR) (Muhtaj, 2008).

Prinsip pertanggungjawaban negara bersifat melekat pada negara tersebut, artinya negara wajib memberikan ganti rugi manakala terjadi kerugian akibat kelalaian yang dilakukan oleh negara. Salah satu contoh ganti rugi yang berkaitan dengan HAM 
diatur dalam dalam Pasal 2 ayat (3) ICCPR. Pasal ini menyebutkan dan mengatur bahwa negara wajib melakukan pemulihan terhadap korban pelanggaran HAM secara efektif meskipun pelanggaran tersebut dilakukan oleh aparatnya sendiri (ICCPR, 1976).

Ada dua istilah berbeda dalam prinsip tanggung jawab negara yaitu responsibility dan liability. Responsibility memiliki makna apa yang harus dipertanggungjawabkan kepada satu pihak, sedangkan liability memiliki makna tanggung jawab untuk mengganti rugi sebuah kerusakan yang telah terjadi. Jadi responsibility dan liability sama-sama mengandung unsur mengikat pihak yang bersalah dan memperbaiki akibat kesalahannya (Putra, Yuliartini, \& Mangku, 2018). Sebagaimana kita ketahui bahwa tanggung jawab negara akan muncul akibat adanya suatu tindakan yang dianggap salah secara internasional (international wrongful act). Sederhananya jika suatu negara melanggar kewajiban internasional maka negara tersebut bertanggung jawab atas pelanggaran yang dilakukannya. Dalam Draft Article of Law Commission, dijelaskan bentuk-bentuk tanggung jawab negara antara lain: (ILC, 2001).

a. Tindakan penghentian (cessation);

b. Tidak mengulangi sebuah tindakan (non repetition);

c. Tindakan perbaikan (reparation) yang terdiri dari restitusi, kompensasi atau kombinasi keduanya.

Pertanggungjawaban negara merupakan seperangkat aturan internasional yang mengatur tentang konsekuensi pelanggaran kewajiban internasional, salah satunya adalah pelanggaran HAM (Yustitianingtyas, 2014). Pelanggaran HAM terhadap etnis Rohingya diawali dengan adanya sebuah kebijakan yakni Undang-Undang Kewarganegaraan pada tahun 1982 yang menghapuskan etnis Rohingya sebagai etnis yang diakui oleh Myanmar (Green, Macmanus, \& Venning, 2015). Akibat dari peraturan ini adalah etnis Rohingya tidak memiliki kewarganegaraan yang menimbulkan sikap diskriminasi kian merajalela.

Teori hak kodrati (natural rights theory) secara jelas menyebutkan bahwa hak-hak asasi adalah hak yang bersifat kodrati bawaan dari sifat manusia dan dimiliki oleh setiap individu tanpa terkecuali. Hak-hak asasi ini diperoleh karena semata-mata kondisinya sebagai manusia (Asmarani, 2015). Berkaitan dengan teori ini John Locke menyebutkan sebuah pemikiran bahwa setiap individu dikaruniai oleh alam suatu hak yang melekat yakni hak untuk hidup, hak atas kebebasan (tidak diperbudak), dan hak atas kepemilikian yang tidak dapat dicabut atau diambil oleh siapapun bahkan oleh negara. Hak-hak ini juga tidak dapat juga dikurangi atau dipindah tangankan dari manusia ke manusia lain (Philip, 2016). John Locke juga menyatakan bahwa dalam konteks HAM negara hadir untuk melayani kepentingan dan memenuhi hak asasi tersebut. Selain itu, dalam teori negara hukum disebutkan bahwa sebuah negara hukum atau negara daulat haruslah mempertimbangkan aspek hak asasi dalam setiap tindakannya (Atmaja, \& Budhiarta, 2009). Bentuk perhatian sebuah negara terhadap HAM adalah 
Jurnal Pembangunan Hukum Indonesia

Volume 2, Nomor 2, Tahun 2020
Program Studi Magister Ilmu Hukum Fakultas Hukum Universitas Diponegoro senantiasa mempertimbangkan HAM dalam membuat setiap kebijakan maupun peraturan perundang-undangan lainnya. Selain dua teori di atas, penelitian ini juga menggunakam teori kedaulatan negara untuk menganalisis permasalahan penanganan pelanggaran HAM di Myanmar.

Myanmar diduga melakukan sebuah tindakan pelanggaran HAM. Pelanggaran HAM yang dilakukan oleh Myanmar perlu lebih diidentifikasikan untuk mengetahui kaitannya dengan tanggung jawab negara. Pelanggaran HAM bisa dilakukan dengan sengaja berupa tindakan langsung maupun tindakan tidak langsung dengan melakukan pembiaran terhadap pelaku pelanggar HAM. Sebagai pemangku HAM, Myanmar telah melalaikan kewajibankewajibannya dan telah melakukan pelanggaran HAM. Adanya tindakan yang merugikan yaitu pelanggaran HAM dalam negeri menimbulkan tanggung jawab negara untuk menyelediki, menuntut dan mengadili pelaku pelanggaran HAM tersebut. Negara melalui badan dan oragannya wajib melakukan tindakan penegakan hukum dan HAM.

Berdasarkan uraian di atas, dapat diketahui bahwa negara Myanmar dengan kekuasaannya telah mendiskriminasi etnis Rohingya dengan kebijakan yang mereka buat. Diskriminasi terhadap etnis Rohingya telah menimbulkan pelanggaran HAM berat dan krisis kemanusiaan yang kian berlanjut. Dari latar belakang yang telah dipaparkan maka dapat dirumuskan permasalahan sebagai berikut; (1) Apa kewajiban negara Myanmar dalam aspek HAM; (2) Bagaimana gambaran pelanggaran HAM yang dilakukan oleh Myanmar terhadap etnis Rohingya; (3) Bagaimana penerapan prinsip pertanggungjawaban negara terhadap kasus pelanggaran HAM etnis Rohingya di Myanmar.

Sejauh penelusuran penulis ada beberapa artikel yang terkait dengan tulisan ini. Artikel yang ditulis oleh Katherine Southwick yang berjudul Straining to Prevent The Rohingya Genocide: A sociology of Law Prespective, jurnal ini membahas pelanggaran HAM di Myanmar dari sudut pandang sosiologi hukum serta upaya pencegahan genosida. Perbedaan penelitian oleh Katherine dengan penelitian ini terletak pada fokus penelitian, Katherine lebih fokus terhadap upaya pencegahan genosida (Southwick, 2018).

Artikel kedua ditulis oleh Haradhan Kumar Mohajan yang berjudul The Rohingya Muslims in Myanmar are Victim of Genocide, jurnal ini mengkaji konflik etnis Rohingya dari sudut pandang viktimologi. Perbedaan penelitian oleh Mohajan dengan penelitian ini terletak pada fokus penelitian, Mohajan lebih fokus pada kajian viktimologi terhadap genosida di Myanmar (Mohajan, 2018).

Artikel ketiga ditulis oleh Adam Jones yang berjudul The Rohingya: Genocide in Myanmar jurnal ini memaparkan fakta-fakta diskriminasi dan pelanggaran HAM yang terjadi di Myanmar. Perbedaan penelitian oleh Jones dengan penelitian ini terletak pada fokus penelitian, Jones lebih fokus mendeskripsikan fakta pelanggaran HAM etnis Rohingya yang berujung pada kejahatan genosida (Jones, 2019). 
Jurnal Pembangunan Hukum Indonesia

Volume 2, Nomor 2, Tahun 2020
Program Studi Magister Ilmu Hukum Fakultas Hukum Universitas Diponegoro
Artikel keempat ditulis oleh Gita Wanandi dkk yang berjudul "Perlakuan Diskriminasi Terhadap Etnis Rohingya oleh Myanmar Dalam Prespektif Hukum Internasional" jurnal ini membahas pelanggaran ketentuan hukum Internasional khusunya dalam aspek HAM yang dilakukan oleh pemerintah Myanmar. Perbedaan penelitian oleh Gita dengan penelitian ini terletak pada fokus penelitian. Penelitian ini mengkaji pelanggaran HAM di Myanmar dengan prinsip pertanggungjawaban negara (Wanandi, Diantha, \& Arsika, 2015).

Artikel kelima ditulis oleh Avianti Susanti yang berjudul "Penyelesaian Kasus Pelanggaran HAM Berat Terhadap Etnis Rohingya di Myanmar Berdasarkan Hukum Internasional" jurnal ini mengkaji pelanggaran HAM yang terjadi di Myanmar berikut penyelesaian berdasarkan hukum internasional. Perbedaannya, artikel ini tidak membahas penyelesaian dengan prinsip pertanggungjawaban negara (Susanti, 2018).

Berdasarkan artikel-artikel tersebut penulis belum menemukan kajian penerapan prinsip pertanggungjawaban negara terhadap kasus pelanggaran HAM terhadap etnis Rohingya. Oleh karena itu penulis dalam karya ilmiah ini akan mengkaji kasus yang sama namun dalam sudut pandang yang berbeda yaitu prinsip pertanggungjawaban negara.

\section{B. METODE PENELITIAN}

Metode pendekatan yang digunakan dalam penelitian ini adalah metode pendekatan doktrinal atau yuridis normatif. Penelitian ini meletakkan hukum sebagai asas-asas, norma, kaidah dan peraturan perundang-undangan (HS, Nurbani, 2014). Sumber data yang utama dalam penelitian hukum doktrinal adalah data kepustakaan. Di dalam kepustakaan hukum, sumber data disebut dengan bahan hukum. Bahan hukum yang dikaji dan dianalisis dalam penelitian doktrinal terdiri dari Bahan hukum primer, bahan hukum sekunder, dan bahan hukum tersier (HS, Nurbani, 2014). Spesifikasi penelitian ini adalah deskriptif analitis. Adapun jenis dan data peneltian ini diperoleh dengan kajian kepustakaan. Data yang diperoleh akan dianalisis secara kualitatif.

\section{HASIL DAN PEMBAHASAN}

\section{Kewajiban Negara Untuk Penegakan Hukum dan HAM}

Hukum Internasional menetapkan negara sebagai salah satu subjek hukum internasional. Khusus dalam aspek HAM negara ditetapkan sebagai entitas utama yang bertanggung jawab melindungi, menegakan, menghormati, dan memajukan HAM terutama untuk warga negaranya masing-masing. Tanggung jawab ini muncul didasarkan pada status negara yang juga merupakan international person dan menjadi pihak dari perjanjian internasional tentang HAM, baik berupa konvensi, konvenan, statuta atau bentuk perjanjian lainnya (Rahmandani, 2019).

Secara garis besar, kewajiban negara yang paling mendasar dalam aspek HAM adalah 
kewajiban untuk menghormati (obligation to respect), kewajiban untuk memenuhi (obligation to fulfill), dan kewajiban untuk melindungi (obligation to protect). Kewajiban untuk menghormati (obligation to respect) secara luas diartikan dengan sikap negara untuk menahan diri supaya tidak melakukan campur tangan (intervensi) kecuali sesuai dengan hukum yang berlaku. Kewajiban untuk memenuhi (obligation to fulfill) adalah kewajiban negara untuk mengambil tindakan baik secara legislatif maupun administratif dan secara praktis dalam rangka memenuhi dan menjamin pemenuhan dan pelaksanaan HAM. Kewajiban untuk melindungi (obligation to protect) dapat diartikan sebagai kewajiban negara untuk melindungi HAM setiap individu yang ada dalam kekuasaannya dari berbagai bentuk pelanggaran HAM. Perlindungan HAM meliputi perlindungan dari pelanggaran yang dilakukan oleh negara sendiri atau entitas non negara. Kewajiban untuk menghormati, memenuhi, dan melindungi HAM tidak dapat diingkari oleh pihak manapun termasuk negera karena hal ini merupakan kewajiban untuk melindungi kepentingan umat manusia (obligations erga omnes) (Setiaji, Ibrahim 2017).

Kewajiban ini akan melahirkan suatu tanggung jawab. Secara umum, kewajiban yang harus diemban oleh negara kewajiban untuk menghormati, memenuhi, dan melindungi HAM setiap individu yang berada di bawah kekuasaannya atau yurisdiksinya. Konsekuensi dari kewajiban ini adalah apabila negara tidak menunaikan kewajibannya maka negara dianggap telah melakukan pelanggaran HAM. Selain itu ada kewajiban lain yang harus dilakukan oleh negara yaitu kewajiban negara untuk menegakan HAM. Maka apabila terjadi pelanggaran HAM di suatu negara maka negara tersebut wajib hukumnya untuk melakukan penegakan hukum (Jailani, 2011).

Muladi menyebutkan langkah yang harus dilakukan oleh negara dalam rangka menegakan hukum dan HAM. Diantara langkah-langkah tersebut antara lain; pertama, negara harus menerapkan prinsip equality before the law; kedua, mencegah segala impunitas; ketiga, menghentikan konflik dan membentuk komisi kebenaran dan rekonsiliasi; keempat; mengadili pelaku melalui pengadilan HAM dan harus didasarkan pada peraturan dalam instrumen hukum internasional untuk menjamin standar lembaga penegakan hukum dan kelima, senantiasa memastikan kejahatan tersebut tidak terulang lagi (Muladi, 2011).

\section{Pelanggaran HAM Terhadap Etnis Rohingya Di}

\section{Myanmar}

Rakhine merupakan salah satu provinsi di negara Myanmar yang terbentang memanjang sepanjang $560 \mathrm{~km}$ di bagian paling utara negara Myanmar. Provinsi ini berbatasan langsung dengan negara Bangladesh di barat lautnya. Mayoritas penduduknya adalah Budha Rakhine sekitar 2,1 juta jiwa dan sisanya adalah Muslim Rohingya sekitar 1 juta jiwa. Etnis Rohingya sebagian besar menetap di salah satu kota kecil Rakhine yaitu kota Maungdaw dan Buthidaung (Galache, 2016). Hubungan sosial dua etnis ini sangatlah harmonis sampai terjadinya konflik di tahun 2012. 
Jurnal Pembangunan Hukum Indonesia

Volume 2, Nomor 2, Tahun 2020
Program Studi Magister Ilmu Hukum Fakultas Hukum Universitas Diponegoro
International State Crime Inisiative (ISCI) memparkan sebuah temuan bahwa pemerintah Myanmar sangat berperan dalam kekerasan yang dialami etnis Rohingya kini. Pemerintah Myanmar telah melakukan suatu manipulasi dan propaganda dengan menyebarkan kabar terhadap orang-orang Rakhine bahwa musuh mereka bukanlah pemerintah Myanmar melainkan orang-orang muslim Benggala (etnis Rohingya). Propaganda yang dilakukan berupa kampanye untuk melawan muslim Benggala yang ada di Rakhine karena keberadaan mereka di Rakhine hanya akan merampas wilayah dan menguasai perekonomian kota Rakhine (Green, Macmanus, \& Venning, 2018).

Negara Myanmar telah merdeka sejak tahun 1948. Meskipun sudah merdeka sejak tahun 1948, namun kondisi politik dalam negeri Myanmar sendiri masih bergejolak. Sejak tahun 1948 sekiranya ada beberapa peristiwa penting terkait adanya pelanggaran HAM terhadap etnis Rohingya. Pelanggaran HAM ini diawali dengan adanya peristiwa kudeta militer pada tahun 1962. Pada tahun 1982 Pemerintah Burma (Myanmar) menghapus etnis Rohingya dari daftar ras dan etnis Burma. Ketetapan ini dituangkan dalam Undang-Undang Kewarganegaraan Burma 1982. Konsekuensinya etnis Rohingya kehilangan status kewarganegaraannya dan dicabut semua hak-hak lainnya (Kusumo, 2014). Semua pelanggaran HAM yang terjadi hingga saat ini berawal dari penghapusan status kewarganegaraan etnis Rohingya, sehingga mereka rentan akan diskriminasi. Diskriminasi yang mereka alami diantaranya pembatasan angka kelahiran dengan pembatasan pernikahan etnis Rohingya, anak-anak Rohingya yang terlahir tidak diberi akta kelahiran, tempat ibadah dan sekolah-sekolah muslim Rohingya dihancurkan, pembatasan pergerakan mereka hingga dicabutnya hak-hak ekonomi, kesehatan, dan pendidikan bagi etnis Rohingya (Thontowi, 2013).

Puncak dari segala diskriminasi terjadi pada tahun 2012 ketika terjadi konflik antara etnis Budha Rakhine dan etnis Muslim Rohingya. Konflik ini menyebabkan eksodus dalam skala besar etnis Rohingya dengan menggunakan perahu menuju negara-negara sekitar Myanmar untuk menyelamatkan diri. Bangladesh, Indonesia, Malaysia, dan Thailand menjadi negara tujuan mereka untuk memperoleh suaka. Sampai bulan Juni tahun 2015, United Nations High Commissioner for Refugees (UNHCR) mengestimasi jumlah pengungsi Rohingya sebanyak 150.000 orang (Green, Macmanus, \& Venning, 2018).

Setelah peristiwa eksodus besar-besaran pada tahun 2012, pada tanggal 26 Agustus 2017 peristiwa pelanggaran HAM berat pun terjadi dan lebih parah dibanding peristiwa sebelumnya. Peritiwa ini pun kemudian dikenal dengan istilah "operasi pemusnahan" yang dilakukan oleh anggota militer Myanmar (Tatmandaw). Operasi ini pun mengakibatkan kurang lebih 725.000 orang Rohingya melarikan diri ke Bangladesh. Operasi pemusnahan ini merupakan suatu bencana HAM. Tim Pencari Fakta pun menyebutkan jumlah korban meninggal 
Jurnal Pembangunan Hukum Indonesia

Volume 2, Nomor 2, Tahun 2020
Program Studi Magister Ilmu Hukum Fakultas Hukum Universitas Diponegoro akibat operasi ini kurang lebih sekitah 10.000 jiwa (Human Rights Council, 2018).

\section{Pertanggungjawaban Negara Myanmar atas Pelanggaran HAM Terhadap Etnis Rohingya}

Timbulnya pelanggaran HAM berat di suatu negara tentunya menimbulkan sebuah pertanyaan tentang siapa yang bertanggung jawab atas semua kerusakan yang terjadi. Dalam penelitian ini penulis mencoba memaparkan perihal pertanggungjawaban ketika terjadi suatu pelanggaran HAM. Penulis mengkaji berdasarkan prinsip pertanggungjawaban negara.

Pelanggaran HAM yang dilakukan oleh Pemerintah Myanmar terhadap etnis Rohingya mengindikasikan kejahatan genosida. Menurut Pasal 6 Statuta Roma 1998, genosida merupakan kejahatan yang dilakukan secara sistematis dengan tujuan untuk menghancurkan atau memusnahkan seluruh atau sebagian etnis, ras, suku, dan agama dengan cara antara lain:

a. Membunuh suatu kelompok;

b. Menyebabkan luka parah atau kerusakan fisik maupun mental suatu kelompok;

c. Tindakan dengan sengaja mengancam jiwa suatu kelompok dan menyebabkan luka fisik baik sebagian maupun keseluruhan;

d. Memindahkan anak-anak secara paksa dari suatu kelompok ke kelompok lain;

e. Pengusiran atau pemindahan penduduk secara paksa.

Secara harfiah genosida diartikan sebagai pembunuhan atau pemusnahan suatu ras atau kelompok dengan sengaja. Genosida dipertimbangkan sebagai subkategori dari kejahatan terhadap kemanusiaan (Sari, 2015). Faktor-faktor terjadinya genosida disebabkan faktor ras, suku, dan agama. Perbedaan ras oleh beberapa kelompok di dunia menyebabkan terjadinya kejahatan genosida. Genosida dengan faktor penyebab ras sudah terjadi sejak beberapa tahun ke belakang. Contohnya konflik apartheid yang terjadi di Afrika Selatan selama abad ke-20. Apartheid merupakan bentuk segregasi rasial yang menimbulkan diskriminasi politik, hukum, dan ekonomi yang memisahkan antara ras warna kulit hitam, ras campuran, serta India dan Afrika Selatan putih (Kurniawan, 2017). Latar belakang suku yang berbeda dari suatu kelompok juga seringkali menjadi faktor penyebab genosida. Maka terkadang adanya suatu diskriminasi terhadap suatu kelompok terutama kelompok minoritas bukan hanya karena perbedaan etnis secara umum seperti agama, atau faktor ekonomi dan politik, tetapi melainkan juga karena masyarakat sipil suatu tempat itu sendiri (Kurniawan, 2017). Faktor agama seringkali menjadi salah satu faktor terjadinya genosida. Perbedaan latar belakang agama biasa dijadikan alasan mendasar terjadinya konflik dan perpecahan. Dimana kelompok pemeluk agama mayoritas akan menekan dan bahkan menindas kelompok agama minoritas. Konflik dengan latar belakang agama akan terus berlanjut jika tidak dilakukan inisiatif untuk menyelesaikan akar permasalahan tersebut. Penyelesaian konflik antar agama tentunya membutuhkan peran pemuka 
Jurnal Pembangunan Hukum Indonesia

Volume 2, Nomor 2, Tahun 2020
Program Studi Magister Ilmu Hukum Fakultas Hukum Universitas Diponegoro agama atau tokoh agama yang dapat membina dan mengarahkan kelompoknya untuk tidak melakukan kekerasan terhadap sesama manusia (Kurniawan, 2017).

Dalam konteks hukum internasional, negara adalah sebagai pemikul tanggung jawab dalam rangka penegakan hukum atas pelanggaran HAM. Tanggung jawab sifatnya absolut tidak dapat dikurangi atau bahkan dicabut karena alasan-alasan politik, ekonomi, maupun budaya. Hugo Grotius dalam bukunya De Jure Belli AC Pacis 1625 menyebutkan bahwa negara dan pejabat pemerintahannya bertanggungjawab terhadap kejahatan yang dilakukan oleh orang yang berada di bawah kekuasaan dan pengendaliannya (Setiyono, 2010). Negara bertanggung jawab memenuhi, melindungi, menghormati, dan menjamin pemenuhan HAM warga negaranya. Maka jika ada sebuah tindakan yang melanggar HAM yang fundamental bagi warga negaranya, negara dalam hal ini pemerintah ikut bertanggung jawab bisa karena tindakannya membiarkan terjadi pelanggaran HAM atau pemerintah sendiri yang memerintahkan perbuatan tersebut melalui kebijakan yang pemerintah buat (Fernandes, 2017).

Menurut perspektif hukum internasional, pelanggaran HAM adalah suatu tindakan yang melanggar kewajiban negara yang telah dituangkan dalam instrumen-instrumen HAM internasional. Pelanggaran HAM bisa dalam bentuk tindakan (acts by commition) atau pembiaran/kelalaian (acts by ommition) (Mardiyono, 2016). Pelanggaran HAM yang menimpa etnis Rohingya di Myanmar sudah jelas menimbulkan tanggung jawab negara. Tanggung jawab negara yang dimaksud dalam konteks HAM adalah tanggung jawab untuk menegakan, melindungi, memenuhi, menghormati serta memajukan HAM. Adapun apabila terjadi pelanggaran HAM dalam wilayah yurisdiksinya, maka sebagai aktor utama, negara harus melakukan upaya penghentian untuk kemudian dilakukan penegakan hukum dan HAM. Penegakan hukum dan HAM disini meliputi proses penyelidikan, penuntutan hingga penjatuhan hukuman terhadap pelaku pelanggaran HAM.

Perihal penyelesaian kasus pelanggaran HAM di Myanmar apabila merujuk teori kedaulatan negara, maka negara berdaulat berhak membuat sebuah keputusan tanpa dipengaruhi pihak atau otoritas lain dan memperjuangkan haknya tanpa harus mematuhi kehendak otoritas lain (Thantowi, 2013). Kasus genosida yang terjadi di Myanmar sudah seharusnya menjadi tanggung jawab Myanmar untuk menyelesaikan kasus tersebut secara mandiri. Dengan kedaulatannya, negara Myanmar tidak bisa diintervensi oleh negara atau lembaga hukum lainnya dalam hal penyelesaian kasus genosida etnis Rohingya. Bahkan Mahkamah Pidana Internasional/International Criminal Court (ICC) tidak bisa serta merta mengambil alih kasus ini ke dalam yurisdiksinya karena keberadaan ICC yang hanya besifat komplementaris atau melengkapi sistem peradilan nasional. ICC pun akan sulit menjangkau 
Jurnal Pembangunan Hukum Indonesia

Volume 2, Nomor 2, Tahun 2020
Program Studi Magister Ilmu Hukum

Fakultas Hukum Universitas Diponegoro kasus genosida ini mengingat negara Myanmar juga bukan negara peserta Statuta Roma 1998.

Hal yang perlu digaris bawahi adalah kedaulatan negara memiliki batasan. Pembatasan kedaulatan negara dapat diterapkan apabila kedaulatan tersebut bersinggungan dengan segala aspek HAM. Pembatasan ini diterapkan untuk menjamin kemanaan bagi umat manusia dan terbebas dari penyalahgunaan kekuasaan oleh negara dan aparatnya (Dewi, 2013).

Sebagai negara hukum Myanmar sudah seharusnya dalam membuat peraturan atau kebijakan memperhatikan aspek HAM. HAM yang universal bagi siapapun tanpa melihat siapa ia, ras apa atau agama apa. Semua warga yang berada di bawah yurisdiknya harus terjamin HAM nya karena pemenuhan dan perlindungan HAM adalah kewajiban negara (Susanti, 2014).

Mencuatnya kabar pelanggaran HAM yang terjadi di Myanmar menarik perhatian dunia. Salah satunya adalah negara Gambia. Gambia yang mayoritas penduduknya beragama Islam pada November 2019 memasukan gugatan ke International Criminal Justice (ICJ) atas tuduhan pelanggaran HAM oleh Myanmar yang mengindikasikan genosdia terhadap etnis Rohingya. Gugatan Gambia melawan Myanmar telah mendapatkan dukungan dari Organisasi Kerjasama Islam (OKI) yang beranggotakan 57 negara. Dikarenakan prosedur ICJ, maka hanya satu negara yang boleh memasukan gugatan. Gambia pun terpilih mewakili negara-negara anggota OKI untuk menggugat Myanmar. Pada tanggal 23 Januari 2020, ICJ memutuskan dan memerintahkan Myanmar untuk melakukan upaya-upaya pencegahan genosida. Di sisi lain, ICJ pun menolak bantahan atau argumen yang disampaikan oleh Aung San Suu Kyi (Brown, 2020). Gugatan yang diajukan Gambia menunjukan bahwa kedaulatan suatu negara tidak dapat dijadikan alasan untuk terbebas dari tuntutan atau gugatan yang berkaitan dengan HAM.

Berdasarkan pemaparan di atas, pelanggaran HAM yang terjadi di Myanmar telah menimbulkan benyak korban, kerusakan dan kerugian. Pelanggaran HAM merupakan pelanggaran terhadap instrumen hukum internasional. Draft artikel tanggung jawab negara "Draft Articles on The Responsibilty of States for Internationally Wrongful Acts" yang disusun oleh International Law Commission (ILC), tidak memberikan definisi khusus tentang pertanggungjawaban negara. Pasal 1 Draft tersebut hanya memberi penjelasan kapan tanggung jawab negara timbul, dalam pasal tersebut disebutkan tentang kapan prinsip pertanggungjawaban negara muncul. Prinsip ini muncul ketika suatu negara melakukan tindakan yang salah menurut peraturan hukum internasional (wrongful action). Tindakan yang salah tersebut meliputi negara melakukan (action) atau tidak melakukan (omission) (ILC, 2001). Berdasarkan Draft tersebut maka pihak yang harus dimintai pertanggungjawaban atas semua pelanggaran HAM yang terjadi di Myanmar adalah negara Myanmar. Sebagaimana disebutkan dalam putusan ICJ pada Barcelona Case yang 
Jurnal Pembangunan Hukum Indonesia

Volume 2, Nomor 2, Tahun 2020
Program Studi Magister Ilmu Hukum

Fakultas Hukum Universitas Diponegoro menyebutkan bahwa setiap negara memiliki

kepentingan hukum (legal interest) perihal

perlindungan HAM dan pemenuhannya. Dengan demikian pelanggaran HAM terhadap dua hal tersebut (perlindungan dan pemenuhan HAM) menimbulkan pertanggungjawaban negara (Mangku, 2013).

\section{SIMPULAN}

Negara sebagai pemangku HAM sudah seharusnya dapat menjamin pemenuhan HAM warga negaranya tanpa diskriminasi. Diskriminasi terhadap etnis minoritas Rohingya di Myanmar telah menjadi sorotan dunia internasional. Diskriminasi yang dilakukan pemerintah pun sudah mengarah pada tindakan pelanggaran HAM berat yaitu genosida. Myanmar sebagai negara harus bertanggung jawab atas kejahatan yang menimpa warga negaranya. Bentuk tanggung jawab yang dilakukan salah satunya adalah tindakan penghentian, setelah dihentikan maka penegakan HAM pun harus dilakukan meliputi penyelidikan, penuntutan sampai penjatuhan hukuman. Kedaulatan negara tidak dapat dijadikan alasan Myanmar terbebas dari segala tuntutan atas pelanggaran HAM. Negara Myanmar dapat dituntut dan dimintai pertanggungjawaban atas pelanggaran HAM tersebut. Pertanggungjawaban negara pada hakikatnya akan muncul apabila negara tersebut telah melakukan wrongfull action. Pelangaran HAM merupakan wrongfull action sehingga menimbulkan pertanggungjawaban negara.

\section{DAFTAR PUSTAKA}

\section{BUKU}

Atmaja, I Gede Dewa., \& Budhiarta, I Nyoman Putu. (2018). Teori-Teori Hukum. Malang: Setara Press.

Dewi, Y. (2013). Kejahatan Perang Dalam Hukum Internasional dan Hukum Nasional. Jakarta: Raja Grafindo Persada.

Green, Penny., Macmanus, Thomas., \& Venning, Alicia de la Cour. (2018). Achieved, Genocide Continues: Myanmar's Annihilation of The Rohingya. London: International State Crime Inisiative.

HS, Salim., \& Septiana, Nurbani Erlies. (2014) Penerapan Teori Hukum Pada Penelitian Tesis dan Disertasi. Jakarta: Rajawali Press.

Human Rights Council. (2018). Report of The Independent International Fact-Finding Mission on Myanmar, 39th Session.

Muhtaj, Majda E,. (2008). Dimensi-Dimensi HAM: Mengurai Hak Ekonomi, Sosial, Budaya. Jakarta: PT Raja Grafindo Persada.

Muladi. (2011). Statuta Roma Tahun 1998 Tentang Mahkamah Pidana Internasional Dalam Kerangka Hukum Pidana Internasional dan Implikasinya Terhadap Hukum Pidana Nasional. Bandung: Alumni.

Rahayu. (2015). Hukum Hak Asasi Manusia. Semarang: Badan Penerbit Universitas Diponegoro. 
Jurnal Pembangunan Hukum Indonesia

Volume 2, Nomor 2, Tahun 2020
Program Studi Magister Ilmu Hukum Fakultas Hukum Universitas Diponegoro

\section{JURNAL}

Wanandi, Gita., Diantha, I Made Pasek., \& Arsika, I Made Budi. (2015). Perlakuan Diskriminasi Terhadap Etnis Rohingya oleh Myanmar Dalam Prespektif Hukum Internasional. Kertha Negara, Vol.3, (No.2), pp.1-6.

Asmarani, N. (2015). Teori Hak Asasi Manusia. J urnal Hukum dan Masyarakat, Vol.14, (No.1), p. 28

Fernandes, I. (2017). Telaah Kejahatan Kemanusiaan Terhadap Etnis Rohingya Berdasarkan Hukum Internasional. Jurnal Hukum Das Sollen, Vol.1, (No.2), p. 19-22.

Jailani, M. (2011). Tanggung Jawab Negara Dalam Memberikan Perlindungan Terhadap Hak-Hak Korban Pelanggaran HAM Berat. J urnal Syiar Hukum, Vol.13, (No.1), p. 84.

Jones, A. (2019). The Rohingya: Genocide in Myanmar?, $A B C$ Journal of Advanced Research, Vol.9, (No.3), pp. 60-61.

Kusumo, Ayub Torry S. (2014). Optimalisasi Peran ICC dan Aplikasi Kemanusiaan Sebagai Inisiasi Penyelesaian Kasus Rohingya. Jurnal Dinamika Hukum, Vol.14, (No.3), p. 529.

Kurniawan, N. (2017). Rohingya Case and State Responsibility in the Enforcement of Human Rights. J urnal Konstitusi, Vol.14, (No. 4), pp. 885-889.

Mangku, Dewa Gede S. (2013). Kasus Pelanggaran HAM Etnis Rohingya. Jurnal Media Komunikasi, Vol.12, (No.2), pp. 87-89.
Mardiyono. (2016). Tanggung Jawab Negara dan Mekanisme Penyelesaian Extra Judicial Killings 1965. Jurnal Refleksi Hukum, Vol.1, (No.1), p. 30.

Mohajan, Haradhan K. (2018). The Rohingya Muslims In Myanmar Are Victim of Genocide, $A B C$ Journal of Advanced Research, Vol.7, (No.1), p. 49.

Philip, C. (2016). Tanggung Jawab Negara Terhadap Perlindungan HAM Menurut Hukum Internasional. Jurnal Lex Administratum, Vol. 4, (No.2), p. 36.

Pudjibudono, Widya P. (2019). Critizing The Handling of Rohingya Refugees in Southeast Asia by ASEAN and Its Member. Jurnal Politika, Vol. 10, (No.2), p. 220.

Putra, Ketut Alit., Yuliartini, Ni Putu Rai., \& Mangku, Dewa Gede Sudika. (2018). Analisis Tindak Kejahatan Genosida Oleh Myanmar Kepada Etnis Rohingya Ditinjau Dari Perspektif Hukum Pidana Internasional. Jurnal Komunitas Yustitia, Vol. 1, (No. 1), p. 27.

Rahmandani, F. (2019). Hak dan Kewajiban Sebagai Dasar Nilai Intrinsik Warga Negara Dalam Membentuk Masyarakat Sipil. Jurnal kajian Agama, Vol.4, (No.1), p. 52.

Sari, I. (2015), Kejahatan-Kejahatan Internasional dan Peranan ICC Dalam Penegakan Hukum Pidana Internasional. Jurnal IImiah Hukum Dirgantara, Vol.6, (No.1), pp. 49-50.

Setiaji, Muhammad Luthfan,. \& Ibrahim, Aminullah. (2018). Kajian HAM dalam Negara The Rule of 
Jurnal Pembangunan Hukum Indonesia

Volume 2, Nomor 2, Tahun 2020
Program Studi Magister Ilmu Hukum Fakultas Hukum Universitas Diponegoro
Law. Lex Scientia Law Review, Vol.1, (No.1), p. 76.

Setiyono, J. (2010). Pertanggungjawaban Komando Atas Pelanggaran HAM Berat dan Kejahatan Terhadap Kemanusiaan, Jurnal Masalah Masalah Hukum, Jilid 39, (No.4), p. 98.

Siba, M. Anggela Merici,. \& Qomari'ah, Anggi Nurul. (2018). Pelanggaran HAM Dalam Konflik Rohingya. J urnal of Islamic World and Politics, Vol.2, (No.2), p. 370.

Southwick, K. (2018). Straining to Prevent the

Rohingya Genocide: A Sociology of Law Prespective. Genocide Studies and Prevention, Vol.12, (No.3), pp. 187-188.

Susanti, A. (2014). Penyelesaian Kasus Pelanggaran HAM Berat Terhadap Etnis Rohingya di Myanmar Berdasarkan Hukum Internasional. J urnal Dinamika Hukum, Vol.1, (No.2), pp. 3335.

Thantowi, J. (2013). Perlakuan Pemerintah Myanmar Terhadap Minoritas Muslim Rohingya. J urnal Pandecta, Vol.8, (No.1), p. 44.

Yustitianingtyas, L. (2014). Pertanggungjawaban Negara Dalam Perspektif Hukum Humaniter Dalam Tindakan Agresi. Jurnal Perspektif Hukum, Vol. 14, (No.1), p. 34.

Zaini, Naya A. (2016). Politik Hukum dan HAM. J urnal Panorama Hukum, Vol.1, (No.2), p. 12.

\section{TESIS}

Sawal, Indah A. (2017). Implikasi Krisis Kemanusiaan Rohingya di Myanmar Terhadap Negara-
Negara ASEAN. Tesis Universitas Hasanudin Makassar.

\section{UNDANG-UNDANG}

Draft Article International Law Commission, 1996.

Rome Statute 1998.

International Convenant on Civil and political Rights (ICCPR), 1976.

\section{SUMBER ONLINE}

Galache, C.S. (2016). Rohingya and National Identities in Burma. New Mandala, dapat diakses di http://asiapasific.anu.edu.au/ newmandala/2016/09/22/therohingya-andnational-identities-in-Burma/

Brown, R. L. (2020). Rohingya Ruling: How A Tiny African Country Brought Myanmar to Court, dapat diakses di https://www.csmonitor.com/ layout/set/amphtm//World/Africa/2020/02/13/R ohingya-ruling-how-a-tiny-African-countrybrought-Myanmar 